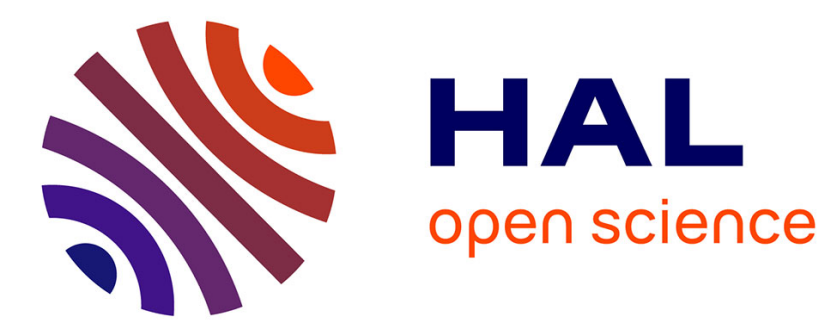

\title{
Palaeozoic collision between the North and South China Blocks, Triassic intracontinental tectonics, and the problem of the ultrahigh-pressure metamorphism
}

Michel Faure, Wei Lin, Patrick Monié, Sébastien Meffre

\section{- To cite this version:}

Michel Faure, Wei Lin, Patrick Monié, Sébastien Meffre. Palaeozoic collision between the North and South China Blocks, Triassic intracontinental tectonics, and the problem of the ultrahigh-pressure metamorphism. Comptes Rendus Géoscience, 2008, 340, pp.139-150. 10.1016/j.crte.2007.10.007. insu-00191534

\section{HAL Id: insu-00191534 \\ https://hal-insu.archives-ouvertes.fr/insu-00191534}

Submitted on 8 Jan 2008

HAL is a multi-disciplinary open access archive for the deposit and dissemination of scientific research documents, whether they are published or not. The documents may come from teaching and research institutions in France or abroad, or from public or private research centers.
L'archive ouverte pluridisciplinaire HAL, est destinée au dépôt et à la diffusion de documents scientifiques de niveau recherche, publiés ou non, émanant des établissements d'enseignement et de recherche français ou étrangers, des laboratoires publics ou privés. 


\title{
Palaeozoic collision between the North and South China blocks, Triassic intracontinental tectonics, and the problem of the ultrahigh-pressure metamorphism
}

\section{Collision paléozoïque entre les blocs de Chine du Nord et du Sud, tectonique intracontinentale triasique et le problème du métamorphisme de ultra-haute pression}

\author{
Michel Faure $^{\text {a, }}$, Wei Lin ${ }^{b}$, Patrick Moniéc and Sébastien Meffre ${ }^{d}$ \\ ${ }^{a}$ Institut des sciences de la Terre d'Orléans, UMR CNRS 6113, université d'Orléans, 45067 \\ Orléans cedex 2, France \\ ${ }^{\mathrm{b}}$ State Key Laboratory of Lithospheric Evolution, Institute of Geology and Geophysics, \\ Chinese Academy of Sciences, Beijing 100029, China \\ ${ }^{\mathrm{c}}$ Géosciences Montpellier, UMR CNRS 5243, université Montpellier-2, 34095 Montpellier \\ cedex 5, France \\ ${ }^{\mathrm{d}}$ School of Earth Sciences, University of Tasmania, Hobart, Tasmania, Australia
}

\begin{abstract}
The Qinling-Dabie Belt represents the boundary between the North and South China blocks (NCB, SCB, respectively), where ultrahigh-pressure (UHP) rocks are widespread. A structural study in eastern Qinling and zircon LA ICPMS dating of the migmatites that form the core of the Central Qinling Unit allows us to argue that continental collision occurred in the Silurian, before $400 \mathrm{Ma}$. In the Late Palaeozoic, from the Devonian to the Permian, the northern margin of SCB experienced a continental rifting. From the Late Permian to Middle Triassic, northward continental subduction of SCB is responsible for the development of a highpressure metamorphism. The age of the UHP metamorphism remains unsettled yet. A twotime genesis, Early Palaeozoic and Early Triassic, is often preferred, but a single Palaeozoic age followed by a Triassic resetting cannot be ruled out.
\end{abstract}

\section{Résumé}

La chaîne Qinling-Dabie représente la limite entre les blocs de Chine du Nord et du Sud, dans laquelle des roches métamorphiques d'ultra-haute pression (UHP) sont très abondantes. Une étude structurale dans le Qinling oriental et des datations ICP-MS de zircon dans les migmatites qui forment le noyau du Qinling central et qui contiennent des restites d'amphibolite à grenat (éclogites rétromorphosées) nous permettent de proposer que la collision continentale s'est produite vers $400 \mathrm{Ma}$, au Silurien. Entre le Dévonien et le Permien inférieur, la marge nord du bloc de Chine du Sud a connu un rifting continental. Au Permien supérieur et au Trias, la subduction continentale vers le nord du bloc de Chine du Sud est responsable d'un métamorphisme de haute pression. L'âge du métamorphisme UHP reste mal contraint. Une évolution diachrone et polyorogénique au Paléozoïque et au Trias inférieur est souvent privilégiée. Mais la formation de toutes les roches de UHP au Paléozoïque inférieur, suivie par une réhomogénéisation isotopique au Trias, ne peut pas être écartée. 
Keywords: Qinling-Dabie Belt; Palaeozoic collision; Triassic tectonics; Continental subduction; Ultrahigh-pressure metamorphism

Mots clés: Ceinture Qinling-Dabie Belt; Collision paléozoïque; Tectonique triasique; Subduction continentale; Métamorphisme d'ultra-haute pression

\section{Introduction}

It is well acknowledged that Asia was formed by multiple collisions of continental blocks since the Proterozoic. The North China Block (NCB) and the South China Block (SCB) are two of these major cratons that are welded along the Qinling-Dabie-Sulu Belt. This chain became very famous when ultrahigh-pressure (UHP) rocks were discovered there [31], [37] and [40] (Fig. 1). The protoliths of these UHP rocks are Proterozoic SCB-derived continental rocks, namely mafic dykes, granites, marbles, and quartzites. The UHP metamorphism developed during the north-directed subduction of SCB below NCB. Thus, it is tempting to conclude that the age of the NCB-SCB collision is the same as that of the UHP metamorphism. Numerous geochronological studies of the metamorphic rocks provide radiometric ages ranging from Neoproterozoic to Cretaceous (e.g., [1], [11], [12], [13] and [32]). As a matter of fact, numerous $\mathrm{U}-\mathrm{Pb}, \mathrm{Sm}-\mathrm{Nd}$ and ${ }^{40} \mathrm{Ar} /{ }^{39} \mathrm{Ar}$ ages cluster around 240 $210 \mathrm{Ma}$ and therefore, a Triassic age is widely accepted for the age of the NCB-SCB collision [13], [20] and [25].

Furthermore, field studies led to contrasted conclusions. A pioneer work in eastern Qinling and Dabieshan argued for an Early Palaeozoic collision followed by a Triassic intracontinental deformation [27], [28] and [40]. This view was also supported by some radiometric dates [35], [46] and [49]. Nevertheless, based on most of radiometric ages yielded by the UHP rocks and in spite of rare structural data, most of authors favour a Triassic collision. In addition to the time problem, several questions are still imperfectly answered. Namely, (i) what is the bulk architecture of the belt? (ii) where is the suture zone ? (iii) is there a magmatic arc attesting to the northward subduction ?; (iv) if not collisional, what is the geodynamic significance of the Triassic event? In the following, some answers to these questions are proposed. After presenting a bulk cross section through the eastern Qinling belt, an interpretative geodynamic model trying to account for the evolution of the Qinling Belt and the age of the UHP metamorphism is discussed.

\section{A cross section through the eastern Qinling Belt}

Due to the Late Mesozoic and Cenozoic tectonics, the western part of the Qinling Belt is formed by narrow parallel stripes of highly dipping rocks separated by wrench faults. Therefore, the bulk architecture of the Qinling Belt is easier to investigate in its eastern part, where the belt is wider. Previous works already dealt with the tectonic evolution of the Qinling belt (e.g., [15], [19], [27], [28], [32], [40], [41] and [47]), but field-based structural cross-sections are rarely provided. During our field survey, we recognized several lithotectonic units roughly similar to those identified by previous authors. In this section, they are presented from north to south (Fig. 2 and Fig. 3). 


\subsection{The Lesser Qinling or North China Block}

It consists of a sedimentary sequence ranging from Cambrian to Triassic underlain by Neoproterozoic sedimentary rocks and Palaeoproterozoic to Archean gneiss and migmatites. Devonian deposits are lacking in North China, thus the Carboniferous rocks directly overlie Cambrian and Ordovician rocks. This unit corresponds to the NCB.

\subsection{The Erlanping magmatic arc}

Due to left-lateral wrenching, this unit is widely exposed in the east, but not observed in the west. Andesites, basalts, dolerite, and sedimentary rocks are intruded by diorite, gabbro, and granodiorite plutons. These magmatic rocks characterized by a calc-alkaline geochemical signature [19] and [41] are interpreted as a magmatic arc formed upon a continental crust. The arc rocks are covered by terrigenous Late Triassic or younger rocks and intruded by Late Palaeozoic plutons [14]. Zircon U-Pb dating of gabbro, tonalite, and trondjemite yields ages ranging between 488 and $470 \mathrm{Ma}$ [19] and [41]. Curiously, the Erlanping arc is interpreted as the result of a south-dipping subduction without any structural evidence [41].

\subsection{The ophiolitic unit}

This unit crops out in the western part of the study area (Fig. 2). In some maps [14] and [33] it is referred to as the 'Kuanping group' and considered as the Proterozoic basement of NCB, or it is grouped with the Erlanping arc [12] and [32]. However, these rocks exhibit quite distinct lithological and metamorphic features from those of the Erlanping arc. Tholeiitic pillow basalts, mafic volcaniclastic rocks, siliceous red pelagic limestones, cherts, and metapelites are the commonest rock types, indicating a deep-sea environment. In the study area, the rocks are highly sheared, but weakly metamorphosed. We place also in the ophiolitic unit some kilometre-scale mafic-ultramafic bodies like those cropping out north of Shangnan and west of Danfeng. Bedded chert yielded Ordovician to Silurian radiolarians [48].

\subsection{The Central Qinling migmatite antiform}

The next unit, to the south, consists of migmatite developed at the expense of orthogneiss, paragneiss, and amphibolite that may form metre- to plurikilometre-sized restites. Although never clearly recognized as migmatite in early works, melanosome and leucosome segregations, contorted folds, mafic concentrations argue for crustal melting. It is worth noting that the migmatite enclose metre to decametre-sized blocks of amphibolite interpreted as mafic restites. In one site, coesite eclogite is been reported [17] and [42]. Nevertheless, conversely to Dabieshan, eclogites are rare. Kyanite relics argue for an early metamorphism with $P-T$ conditions estimated at 1 to $0.7 \mathrm{GPa}$ and $600-650^{\circ} \mathrm{C}$, respectively. This early event is followed by a decompression to 0.8 to $0.6 \mathrm{GPa}$, coeval with a temperature increase to 700 $750{ }^{\circ} \mathrm{C}$, and then isobaric cooling [44]. Anatectic granite crops out in the core of the migmatitic unit. The rather steep foliation of the migmatite defines an upright antiformal structure. Zircon $\mathrm{U} / \mathrm{Pb}$ and whole-rock $\mathrm{Rb} / \mathrm{Sr}$ ages of the migmatite range from $1 \mathrm{Ga}$ to $380 \mathrm{Ma}$ [32 and enclosed references]. However, since the description of the rock lithology is not always provided in the literature, it is not easy to know what has been exactly dated. Therefore, a new zircon LA ICP-MS dating has been carried out (cf. below). 


\subsection{The Devonian terrigenous basin}

To the south, the Central Qinling migmatitic antiform is bounded by a 5-km-thick series of sandstone, mudstone, conglomerate, and rare limestone, called the Liuling unit [12] and [32]. This terrigenous unit is palaeontologically dated as Devonian based on brachiopods and corals [14] and [33]. Sedimentological studies suggest that conglomerate yielding granite, gneiss, gabbro and peridotite pebbles derived from a northern source, likely the migmatitic unit [9], [45] and [47]. It is also worth noting that these Devonian facies are quite different from those that crop out in the South China Block. Conversely to the northern migmatite unit, this one is weakly deformed and metamorphosed. A HT metamorphism, characterized by biotite, garnet or andalousite, observed in most pelitic parts of the series, is well developed. Due to the Danfeng strike-slip fault, the primary relationships between the Devonian terrigenous series and the migmatitic unit are not observed, but it is interpreted as a molassic trough in front of the Qinling Belt [27] and [45].

\subsection{The Douling basement wedge}

Immediately south of the Devonian basin, a series of micaschist, gneiss, migmatite, known as the 'Douling group', crops out [14] and [32]. Lithologically, this unit partly resembles the migmatitic unit, although other metamorphic rock types are also present there. For the sake of simplicity, the two units are presented in Fig. 2 with the same pattern. The Douling unit overthrusts the South Neoproterozoic metasedimentary rock, of probably Sinian age. Thus, as shown in map and cross-section (Fig. 2 and Fig. 3), the Douling Unit is interpreted as a southdirected basement wedge.

\subsection{The Wudangshan dome}

The southernmost part of the eastern Qinling Belt consists of a wide area of Neoproterozoic quartzite, sandstone, conglomerate, and pelite intruded by mafic rocks (diabase sills and dyke, basalt, tuff, and microgabbro). This series is overlain by Palaeozoic sedimentary rocks ranging from Cambrian to Permian, and more rarely by Early Triassic sandstones (Fig. 2). However, some of the mafic dykes formerly considered as Proterozoic have been dated as Early Devonian by the U-Pb method on zircon [29]. The northern part of the Wudangshan massif experienced a HP metamorphism well preserved in mafic rocks. Blue amphibole (riebeckite) and phengitic white mica yield lime ${ }^{40} \mathrm{Ar} /{ }^{39} \mathrm{Ar}$ ages ranging between 230 and $215 \mathrm{Ma}$ [27] are observed. To the west, a high-temperature metamorphism responsible for the growth of biotite, muscovite, garnet, sillimanite, and andalousite overprints the HP one. This unit, characterized by a pervasive foliation, locally deformed by gentle upright folds, is known as the Wudangshan antiform or dome [27] and [40]. Its structural evolution will be presented in the forthcoming section.

\subsection{The Yangtze foreland}

This Proterozoic to Palaeozoic series, belonging to the South China Block (SCB), represents the southern foreland of the Qinling Belt. These sedimentary rocks are folded by east-west, south-verging folds that involve Permian and Early Triassic sandstone.

In the study area, the Jurassic beds that unconformably overlie the older rocks are undeformed. However, according to geological maps, farther south, the Jurassic beds are also 
folded, attesting to a progressive south-propagating deformation [14]. The Wudangshan metamorphic rocks overthrust to the south the SCB Palaeozoic series, but the present contact is probably not primary, since a brittle thrust places Neoproterozoic rocks upon Triassic and Jurassic ones. When dealing with the pre-Jurassic tectonics, the en-echelon folding of the Yangtze foreland suggests that a left-lateral component of shear took place during or after the thrusting.

The bulk architecture of the above-presented units is shown in Fig. 3. In the northern part of the Qinling Belt that belongs to the North China Block, the deformation is weak. Southverging folds and brittle thrusts involve the Cambrian to Ordovician series. Sometimes an axial planar cleavage develops during the folding, but the associated metamorphism is absent. Locally in the slaty cleavage surfaces, a north-south-trending lineation marked by elongated clasts or quartz fibres can be observed. Low-angle ductile shear zones also indicate a top-tothe-south shearing.

The ophiolitic suture is located south of the Erlanping magmatic arc. South of the suture zone, the Central Qinling migmatitic unit encloses HP amphibolites and eclogites. This unit corresponds to the SCB basement that experienced a post-collisional crustal melting. The palaeontological ages of the Devonian basin comply with the radiometric ones, indicating that the NCB-SCB collision occurred after the arc magmatism that took place at ca $480 \mathrm{Ma}$ [41] and before the deposition of the terrigenous rocks [27] and [45]. South of the suture, all units exhibit a steeply dipping attitude due to the horizontal shearing related to the sinistral wrenching that deforms the Devonian series. Conversely, in the South Qinling area, the main tectonic and metamorphic events are Triassic in age. A south-directed thrusting, coeval with kilometre-scale structures, is characterized by a rather flat-lying foliation developed during the burial of the SCB Neoproterozoic series below the pre-Devonian Qinling orogen. As discussed below and in agreement with previous authors (e.g., [12], [27] and [32], the East Qinling section shows a polyorogenic evolution. The Erlanping magmatic arc, the ophiolitic suture, the Central Qinling migmatite, and the Devonian molassic basin suggest that the collision occurred in the Early Palaeozoic. However, the Triassic synmetamorphic deformation of the Wudangshan represents an intracontinental tectonic event. Structural analyses and radiometric dates presented in the following sections agree with this preliminary conclusion.

\section{Microtectonic analysis and kinematic insights}

A detailed microstructural analysis is beyond the scope of this paper. Only the main geometric and kinematic features are given here. Our structural survey allows us to distinguish at least three main tectonic events.

\subsection{The early top-to-the-south event}

In the central part of the Qinling Belt, the gneissic and migmatitic foliation exhibits variable trends and dips, as it is refolded by a NW-SE-trending antiform (Fig. 2A). The foliation contains a north-south- to NE-SW-trending stretching and mineral lineation (Fig. 2B). When restored to a flat-lying geometry, kinematic criteria such as sigma-type asymmetric porphyroclast systems, or shear bands in augen gneiss, observed in sections perpendicular to the foliation and parallel to the lineation, indicate a top-to-the south sense of shear. In particular, the base of the southern ophiolitic massif, north of Shangnan, consists of more than $10 \mathrm{~m}$ of pervasively foliated amphibolite, with a north-south-trending stretching lineation and 
top-to-the-south kinematic indicators (Fig. 2). It is worth noting that these shear criteria observed in non-migmatitic rocks are older than anatexis. Therefore, this ductile event is interpreted here as the result of the emplacement of the ophiolitic nappe above the Central Qinling basement that corresponds to the basement of the SCB.

\subsection{The sinistral wrenching}

On the northern side of the Danfeng fault that separates the Central Qinling migmatite from the Devonian terrigenous unit, a vertical foliation pervasively overprints the early one. On the southern side of the fault, a vertical slaty cleavage develops, mainly in the pelitic rocks, but also in coarser grained ones. Both vertical foliations contain a subhorizontal mineral and stretching lineation along which left-lateral shear criteria are observed. The planar and linear fabric elements are associated with the left-lateral wrenching along the Danfeng fault. Eastwest- to NW-SE-trending upright folds, associated with an axial planar cleavage, are also related to left-lateral wrenching along the Danfeng fault (Fig. 2).

\subsection{The Wudangshan doming}

More to the south, in the Wudangshan, the main microstructure consists in a widespread bedding-parallel foliation that globally draws an antiformal shape of the Wudang dome. Nevertheless, the regular dome shape is undulated by second-order folds (Fig. 3). The foliation contains a conspicuous north-south- to NNE-SSW-trending mineral and stretching lineation marked by elongated quartz grains and rods, mica clots, or high-temperature slickenlines (Fig. 4C and D). This lineation is associated with contrasted senses of shear (Fig. 4).

Both in the field and in thin section, kinematic indicators are well developed. Top-to-thesouth shearing is indicated by asymmetric quartz veins, mica fish, and pressure shadows developed in quartz or feldspar clasts in sandstone. Furthermore, similar kinematic criteria indicate a top-to-the-north shearing. However, this north-directed kinematics is also indicated by extensional shear bands cutting through the foliation and indicating that the top-to-thenorth shearing might have developed at the same time, or slightly after, the top-to-the-south shearing.

In the field, it appears almost impossible to distinguish between the two types of lineation recognized in the Wudangshan dome. Nevertheless, the geographic distribution of the top-tothe-south and top-to-the-north kinematics is well delineated (Fig. 2). Top-to-the-south shearing predominates in the southern part of the dome, whereas top-to-the-north shearing is developed in the central and northern parts. A simple explanation of this kinematic pattern can be that top-to-the-south shearing coeval to the formation of HP metamorphism represents the ductile deformation associated with the décollement of the Neoproterozoic series of the SCB from the Proterozoic basement and that the top-to-the-north ductile deformation accommodates the exhumation of the HP rocks. As a whole, the Wudangshan dome can be interpreted as a Triassic metamorphic core complex.

At the scale of the entire study area, the kinematic map derived from the above-described three kinematic events allows us to confirm that top-to-the-south shearing recognized in the Central Qinling unit is not contemporaneous with the ductile shearing recognized in the Wudangshan (Fig. 2). This relative timing is also constrained by radiometric dating. 


\section{Geochronological constraints}

As stated above, the age of the central Qinling migmatite is not well established, since this lithology is not clearly mentioned. Therefore, LA-ICP-MS zircon analyses were performed on a leucosome of migmatite (QL 123), and a migmatized orthogneiss (QL53). The rocks were crushed in a ring mill and sieved $(400 \mu \mathrm{m})$. Non-magnetic and slightly magnetic heavy minerals were separated from the $<400-\mu \mathrm{m}$ fraction using a plastic gold pan and an ironboron-rare earth magnet. Large clear crystals were then picked from the heavy mineral separate and mounted in epoxy. All two samples contained large zircon, monazite, and apatite crystals. The samples were then analysed using a Hewlett Packard 4500 quadrupole ICPMS and a New Wave UP 213-nm laser at the University of Monash, Australia. Ablation was performed in a custom designed chamber in a He atmosphere using a laser pulse rate of $5 \mathrm{~Hz}$ on a $30-\mu \mathrm{m}$-sized beam delivering about $13 \mathrm{~mJ} \mathrm{~cm}^{-2}$. A total of 11 masses was analysed $(\mathrm{Zr}$, $\mathrm{Hf}, \mathrm{Nd}, \mathrm{Hg}, \mathrm{Pb}, \mathrm{Th}, \mathrm{U}$ ), with longer counting time on the $\mathrm{Pb}$ and $\mathrm{U}$ isotopes. Each analysis began with a 30-s gas blank followed by $30 \mathrm{~s}$ with the laser switched on. Mass bias, downhole fractionation, and instrumental drift were corrected by analysing four crystals of the Temora international zircon standard [2] and [3] for every 12 unknown zircons. The correction factors were then checked using 91,500 international zircon standards [38] analysed twice for every 12 unknown zircons. Data reduction was performed using the methods outlined by Black et al. [3]. Weighted averages and Concordia plots were calculated using the isoplot software [26].

The zircon analysed from the migmatitic granite of sample QL53 allows us to calculate a mean age at $402 \pm 6 \mathrm{Ma}$ (Fig. 5). Zircons from the leucosome migmatite QL 123 are more scattered from the Concordia. The metamict grains with a high $\mathrm{U}$ content and $\mathrm{Pb}$ loss were not considered for age calculations. Other grains plot on an isochron with a lower intercept at $414 \pm 20 \mathrm{Ma}$ and an upper one at $1579 \pm 160 \mathrm{Ma}$ (Fig. 6). The latter Proterozoic age is in agreement with a SCB protolith for the orthogneiss. The two Palaeozoic ages at ca 400 and $414 \mathrm{Ma}$ are similar within errors and indicate a Late Silurian to Early Devonian age for the migmatization of the Central Qinling.

These new dating measurements comply with previous $\mathrm{Rb} / \mathrm{Sr}, \mathrm{Sm} / \mathrm{Nd}$ mineral isochrones, as well as with ${ }^{40} \mathrm{Ar} /{ }^{39} \mathrm{Ar}$ biotite and muscovite plateau ages on amphibolite [12], [32], [35] and [49]. According to these radiometric data in the Central Qinling, Ophiolitic Unit and shear zones within the Erlanping arc, the age of the amphibolite facies metamorphism, coeval with the ductile deformation and before crustal melting, can be situated between 420 and $380 \mathrm{Ma}$, i.e. in the Late Silurian-Early Devonian.

\section{A possible geodynamic evolution}

Based on the above-presented data, a tentative geodynamic model can be put forward to account for the evolution of the SCB and NCN interactions. A lithosphere-scale evolution along the East Qinling section is pictured in Fig. 7. The Ordovician Erlanping magmatic arc indicates that the NCB-SCB convergence was accommodated by a northward oceanic subduction. The Late Silurian crustal melting argues for a Silurian collision between the two continents. The migmatite with HP and UHP relics partly accommodated the exhumation of the subducted continental crust of the SCB. The Devonian to Permian history is less documented. During the Devonian, terrigenous sediments supplied from the eroding Qinling orogen were deposited in a foreland basin, roughly parallel to the belt. Thus, the Devonian basin can be interpreted as a molassic trough [27] and [45]. 
In western Qinling, Triassic ophiolites form the Mianlue suture [20] and [29]. In eastern Qinling, such an ophiolite is not documented, even if Early Devonian alkaline mafic rocks are identified in the Wudangshan [16]. Nevertheless, intracontinental rifting of the northern and eastern parts of the SCB appears likely. The kilometre-scale strike-slip faults that rework the Qinling Belt might also partly accommodate the Late Palaeozoic rifting of SCB. However, in the present state of knowledge, this process remains undocumented.

In Middle to Late Triassic, north-south convergence resumes, whereas to the south, the SCB platform is still under extension [30] and [36]. The thinnest and probably hottest part of northern SCB is underthrust below the foreland of the Early Palaeozoic Qinling orogen. The HP metamorphism is associated with this intracontinental subduction. Lastly, the exhumation of the HP rocks accommodated by normal ductile shearing, and coeval with the formation of the Wudangshan dome, appears as a synconvergence process.

\section{Conclusion and discussion}

From the study of eastern Qinling, it can be argued that the collision between NCB and SCB already took place before the Late Silurian, which is the time of post-collisional crustal melting, associated with the exhumation of the SCB continental crust in the Central Qinling Unit. This conclusion is also supported by the paleontological record, which indicates that similar floras grew in NCB and SCB during Carboniferous and Permian [18] and [21]. The Triassic intracontinental subduction that accounts for the development of the HP metamorphism in Proterozoic rocks of SCB continues in Late Triassic and Jurassic times, as documented by palaeomagnetism [10] and [43]. The exhumation of the HP rocks can be seen as a synconvergence process, since top-to-the-north ductile normal faulting and top-to-thesouth thrusting are nearly coeval.

To the east of the Qinling belt, in Hong'an, Dabieshan, Zhangbaling and southern Sulu (Fig. 1), such an Early Triassic HP metamorphism is well documented (e.g., [6], [7], [8], [11], [12], [24], [28], [30], [36] and [37]), but in these areas, conversely to what is sometimes proposed [20], [25] and [29], evidence for a Triassic ophiolitic suture, the so-called 'Mianlue suture' is completely lacking.

It has also been shown that the Early Triassic intracontinental compression followed by ductile extensional shearing is not restricted to the northern margin of SCB, but involves a significant part of eastern SCB. In Lushan and in Wugongshan (Fig. 1), kyanite develops in Neoproterozoic (Sinian) pelite associated with south-directed ductile shearing [4] and [22]. In the Jiulingshan, which belongs to the Neoproterozoic Jiangnan Belt [34], the Precambrian structure is partly reworked by pre-Cretaceous compressional and extensional ductile deformations [5] and [23]. However, in all these areas, there is no evidence for Triassic ophiolites, deep marine rocks, or accretionary prism, conversely to what is sometimes proposed [39].

Lastly, the question of the age of the UHP metamorphism of Qinling-Dabieshan and Sulu areas remains unsolved. Several possibilities can be proposed as working hypotheses: (i) all the UHP rocks formed in Early Palaeozoic and the Triassic ages correspond only to partial resetting due to temperature increase and fluid circulation; (ii) all the UHP rocks formed in Early Triassic; (iii) there are two belts of UHP rocks in Central China, one developed at ca 480-450 Ma and another at 250-230 Ma. This last interpretation is presently preferred by several authors (e.g., [12], [13], [19] and [20]) but not convincingly demonstrated yet. 
Additional structural, petrological and geochronological works are needed in order to solve this problem. Whatever the answer, it is important to emphasize that NCB-SCB collision, in the sense of the initial contact between two continental masses, was already completed in the Early Silurian, at least in the eastern part of the orogen.

\section{Acknowledgements}

Claude Lepvrier is deeply acknowledged to give us the chance to express our view, somewhat different from that of many groups working in Central China, and to allow some additional time to prepare this manuscript.

This work has been funded by the national key basis Research program of China (Grant no. 2005CB422101).

\section{References}

[1] J. Ayers, S. Dunkle, S. Gao and C. Miller, Constraints on timing of peak and retrograde metamorphism in the Dabie Shan Ultrahigh-pressure Metamorphic Belt, East-Central China, using U-Th-Pb dating of zircon and monazite, Chem. Geol. 186 (2002), pp. 315-331.

[2] L.P. Black, S.L. Kamo, C.M. Allen, J.N. Aleinikoff, D.W. Davis, R.J. Korsch and C. Foudoulis, TEMORA 1: a new zircon standard for Phanerozoic U-Pb geochronology, Chem. Geol. 200 (2003), pp. 155-170.

[3] L.P. Black, S.L. Kamo, C.M. Allen, D.W. Davis, J.N. Aleinikoff, J.W. Valley, R. Mundil, I.H. Campbell, R.J. Korsch, I.S. Williams and C. Foudoulis, Improved ${ }^{206} \mathrm{~Pb} /{ }^{238} \mathrm{U}$ microprobe geochronology by the monitoring of a trace-element related matrix effect; SHRIMP, IDTIMS, ELA-ICP-MS, and oxygen isotope documentation for a series of zircon standards,Chem. Geol. 205 (2004), pp. 115-140.

[4] M. Faure, Y. Sun, L.S. Shu, P. Monie and J. Charvet, Extensional tectonics within a subduction-type orogen. The case study of the Wugongshan dome (Jiangxi Province, southeastern China), Tectonophysics 263 (1996), pp. 77-106.

[5] M. Faure, W. Lin and Y. Sun, Doming in the southern foreland of the Dabieshan (Yangtse block, China), Terra Nova 10 (1998), pp. 307-311.

[6] M. Faure, W. Lin, L.S. Shu, Y. Sun and U. Scharer, Tectonics of the Dabieshan (eastern China) and possible exhumation mechanism of ultra high-pressure rocks, Terra Nova 11 (1999), pp. 251-258.

[7] M. Faure, W. Lin, P. Monié, N. Le Breton, S. Poussineau, D. Panis and E. Deloule, Exhumation tectonics of the ultrahigh-pressure metamorphic rocks in the Qinling orogen in E.China. New petrological-structural-radiometric insights from the Shandong peninsula, Tectonics 22 (2003) doi:10. 1029/2002TC001450. 
[8] M. Faure, W. Lin, U. Schärer, L. Shu, Y. Sun and N. Arnaud, Continental subduction and exhumation of UHP rocks. Structural and geochronological insights from the Dabieshan (E. China), Lithos 70 (2003), pp. 213-241

[9] S. Gao, B. Zhang, X. Gu, Q. Xie, C. Gao and X. Guo, Silurian-Devonian provenance changes of South Qinling basins: implications for accretion of the Yangtze (South China) to the North China cratons, Tectonophysics 250 (1995), pp. 183-197

[10] S. Gilder and V. Courtillot, Timing of the North-South China collision from new Middle to Late Mesozoic paleomagnetic data from the North China Block, J. Geophys. Res. 108 (1997), pp. 17713-17727.

[11] B. Hacker, L. Ratsbacher, L. Webb, T. Ireland, D. Walker and D. Suwen, U/Pb zircon ages constrain the architecture of the ultrahigh-pressure Qinling-Dabie orogen, China, Earth Planet. Sci. Lett. 161 (1998), pp. 215-230.

[12] B. Hacker, L. Ratsbacher, J.G. Liou, Subduction, collision and exhumation in the ultrahigh-pressure Qinling-Dabie orogen, in: J. Malpas, C.N.J. Ali, J. Aitchison (Eds.), Aspects of the Tectonic evolution of China, Geol. Soc. Lond. Spec. Publ. 226 (2004) 157175.

[13] B. Hacker, S. Wallis, L. Ratschbacher, M. Grove and G. Gehrels, High-temperature geochronology constraints on the tectonic history and architecture of the ultrahigh-presure Dabie-Sulu orogen, Tectonics 25 (2006), pp. 1-17.

[14] HBGMR: Henan Bureau of Geology and Mineral Resources, Regional geology of Henan Province, Geol. Publ. House, Beijing, China, 1989 (in Chinese, with English abstract).

[15] K. Hsu, Q. Wang, J. Li, D. Zhou and S. Sun, Tectonic evolution of Qinling Mountains, Eclogae Geol. Helv. 80 (1987), pp. 735-752.

[16] J. Hu, Q. Meng, G. Ma, S. Zhang and D. Gao, Basic sill swarms in Wudang Block of the southern Qinling and its geological significance, Geol. Rev. 48 (2002), pp. 353-360.

[17] N. Hu, J. Yang and D. Zhao, Sm-Nd isochron age of eclogite from northern Qinling Mountains, Acta Mineral. Sin. 16 (1996), pp. 349-352.

[18] J.-P. Laveine, Y. Lemoigne, X. Li, X. Wu, S. Zhang and X. Zhao, Paleogeography of Chinain Carboniferous time, in the light of paleobotanical data in comparison with West European assemblages, C. R. Acad. Sci. Paris, Ser. II 304 (1987), pp. 391-394.

[19] M.F. Lerch, F. Xue and A. Kröner, Early Paleozoic Island arc accretion to the North China craton and the ShangDan fault zone: a major plate boundary in eastern Asia, $J$. Geophys. Res. 101 (1996), pp. 17813-17826.

[20] S. Li, T. Kusky, L. Wang, G. Zhang, S. Lai, X. Liu, S. Dong and G. Zhao, Collision leading to multiple-stage large-scale extrusion in the Qinling orogen: insights from the Mianlue suture, Gondwana Res. 12 (2007), pp. 121-143. 
[21] X. Li and X. Wu, Late Paleozoic phytogeographic provinces in China and its adjacent regions, J. Asian Earth Sci. 90 (1996), pp. 41-62.

[22] W. Lin, M. Faure, P. Monié, U. Shäerer, L. Zhang and Y. Sun, Tectonics of SE China, new insights from the Lushan massif (Jiangxi Province), Tectonics 19 (2000), pp. 852-871.

[23] W. Lin, M. Faure, Y. Sun and L. Shu, Compression to extension switch during the Early Triassic orogeny of E. China: the case study of the Jiulingshan massif in the southern foreland of the Dabieshan, J. Asian Earth Sci. 20 (2001), pp. 31-43.

[24] W. Lin, M. Faure, D. Panis and P. Monié, Polyphase deformation in the FeidongZhangbaling Massif (eastern China) and its place in the collision between North China and South China Blocks, J. Asian Earth Sci. 25 (2005), pp. 121-136.

[25] S. Liu, R. Steel and G. Zhang, Mesozoic sedimentary basin development and tectonic implication, northern Yangtse Block, eastern China: record of continent-continent collision, J. Asian Earth Sci. 25 (2005), pp. 9-27.

[26] K.R. Ludwig, Users manual for ISOPLOT/EX, version 3. A geochronological toolkit for Microsoft Excel, Berkeley Geochronology Center, Special Publication, vol. 4, 2003.

[27] M. Mattauer, P. Matte, J. Malavieille, P. Tapponnier, H. Maluski, Z. Xu, Y. Lu and Y. Tang, Tectonics of the Qinling Belt: buildup and evolution of eastern Asia, Nature 317 (1985), pp. 496-500.

[28] M. Mattauer, P. Matte, H. Maluski, Z. Xu, Q. Zhang, Y. Wang, Y., La limite Chine du Nord-Chine du Sud au Paléozoïque et au Trias : nouvelles données structurales et radiométriques dans le massif du Dabieshan (chaîne des Qinling), C. R. Acad. Sci. Paris, Ser. II 312 (1991) 1227-1233.

[29] Q. Meng and G. Zhang, Geologic framework and tectonic evolution of the Qinling orogen central China, Tectonophysics 323 (2000), pp. 183-196.

[30] J. Mercier, M. Hou, P. Vergély and Y. Wang, Structural and stratigraphical constraints on the kinematics history of the southern Tan-Lu Fault Zone during the Mesozoic Anhui Province, China, Tectonophysics 439 (2007), pp. 33-66.

[31] A. Okay, C. Sengor and M. Satir, Tectonics of an ultrahigh-pressure metamorphic terrane: the Dabieshan-Tongbai shan orogen, China, Tectonics 12 (1993), pp. 1320-1334.

[32] L. Ratschbacher, B. Hacker, A. Calvert, L. Webb, J. Grimmer, M. Mc Williams, T. Ireland, S. Dong and J. Hu, Tectonics of the Qinling (Central China): tectonostratigraphy, geochronology, and deformation history, Tectonophysics 366 (2003), pp. 1-53.

[33] SBGMR: Shaanxi Bureau of Geology and Mineral Resources, Regional geology of Henan Province, 13 (1989), Geol. Publ. House, Beijing, China (in Chinese, with English abstract). 
[34] L.S. Shu, G.Q. Zhou, Y.S. Shi and J. Yin, Study of the high-pressure metamorphic blueschist and its Late Proterozoic age in the eastern Jiangnan belt, Chin. Sci. Bull. 39 (1994), pp. 1200-1204.

[35] W. Sun, S. Li, Y. Sun, G. Zhang and Q. Li, Mid-Paleozoic collision in the North Qinling: $\mathrm{Sm}-\mathrm{Nd}, \mathrm{Rb}-\mathrm{Sr}$ and ${ }^{40} \mathrm{Ar} /{ }^{39} \mathrm{Ar}$ ages and their tectonic implications, J. Asian Earth Sci. 21 (2002), pp. 69-76.

[36] J. Vergely and J. Mercier, The kinematics of the Tan-Lu fault zone, Bull. Soc. Geol. France 5 (2007), pp. 355-367.

[37] Q. Wang, M. Zhai and B. Cong, Regional geology. In: B. Cong, Editor, Ultrahighpressure metamorphic rocks in the Dabieshan-Sulu region of China, Science Press, Kluwer Acad. Publishers, Beijing, China (1996).

[38] M. Wiedenbeck, P. Alle, F. Corfu, W.L. Griffin, M. Meier, F. Oberli, A. Vonquadt, J.C. Roddick and W. Speigel, Three Natural Zircon Standards for U-Th-Pb, Lu-Hf, TraceElement and Ree Analyses, Geostandards Newslett. 19 (1995), pp. 1-23.

[39] W.J. Xiao and H.Q. He, Early Mesozoic thrust tectonics of the Northwest Zhejiang region (Southeast China), Geol. Soc. Am. Bull. 117 (2005), pp. 1-17.

[40] Z. Xu, Y. Lu, Y. Tang, M. Mattauer, P. Matte, J. Malavieille, P. Tapponnier and H. Maluski, Deformation characteristics and Tectonic evolution of the eastern Qinling orogenic belt, Acta Geol. Sin. 60 (1986), pp. 23-35.

[41] F. Xue, A. Kroner, T. Reischmann and F. Lerch, Paleozoic pre-and post-collision calcalkaline magmatism in the Qinling orogenic belt, Central China, as documented by zircon ages on granitoid rocks, J. Geol. Soc. Lond. 153 (1996), pp. 409-417.

[42] J. Yang, Z. Xu, L. Dobrizhinetskaya, H. Green, X. Pei, R. Shi, C. Wu, J. Wooden, Y. Wan and H. Li, Discovery of metamorphic diamonds in central China: an indication of a $>4000-\mathrm{km}$-long zone of deep subduction resulting from multiple continental collisions, Terra Nova 15 (2003), pp. 370-379.

[43] Z. Yang, X. Ma, L. Xing, S. Xu and J. Zhang, Jurassic paleomagnetic constraints on the collision of the North and South China Blocks, Geophys. Res. Lett. 19 (1992), pp. 577-580.

[44] Z. You, Y. Han, S. Suo, N. Chen and Z. Zhong, Metamorphic history and tectonic evolution of the Qinling complex, eastern Qinling mountains, China, J. Metamorph. Geol. 11 (1993), pp. 549-560.

[45] Z. Yu and Q. Meng, Late Paleozoic sedimentary and tectonic evolution of the Shangdan suture zone, eastern Qinling, China, J. Asian Earth Sci. 11 (1995), pp. 237-242.

[46] X. Zhai, H. Day, B. Hacker and Z. You, Paleozoic metamorphism in the Qinling orogen, Tongbai Mountains, Geology 26 (1998), pp. 371-374.

[47] G. Zhang, Q. Meng, Z. Yu, Y. Sun, D. Zhou and A Guo, orogenesis and the timing of the Qinling orogen, Sci. China Ser. D 30 (1996), pp. 225-234. 
Comptes Rendus Geoscience

[48] S. Zhang and S. Tang, The discovery of Early Paleozoic radiolarians cherts and plate tectonics in northern Qinling, Shaanxi Geol. 2 (1983), pp. 1-9.

[49] H. Zhang, S. Gao, B. Zhang, T. Luo and W. Lin, Pb isotopes of granitoids suggest Devonian accretion of Yangtse (South China) craton to North China craton, Geology 25 (1997), pp. 1015-1018. 


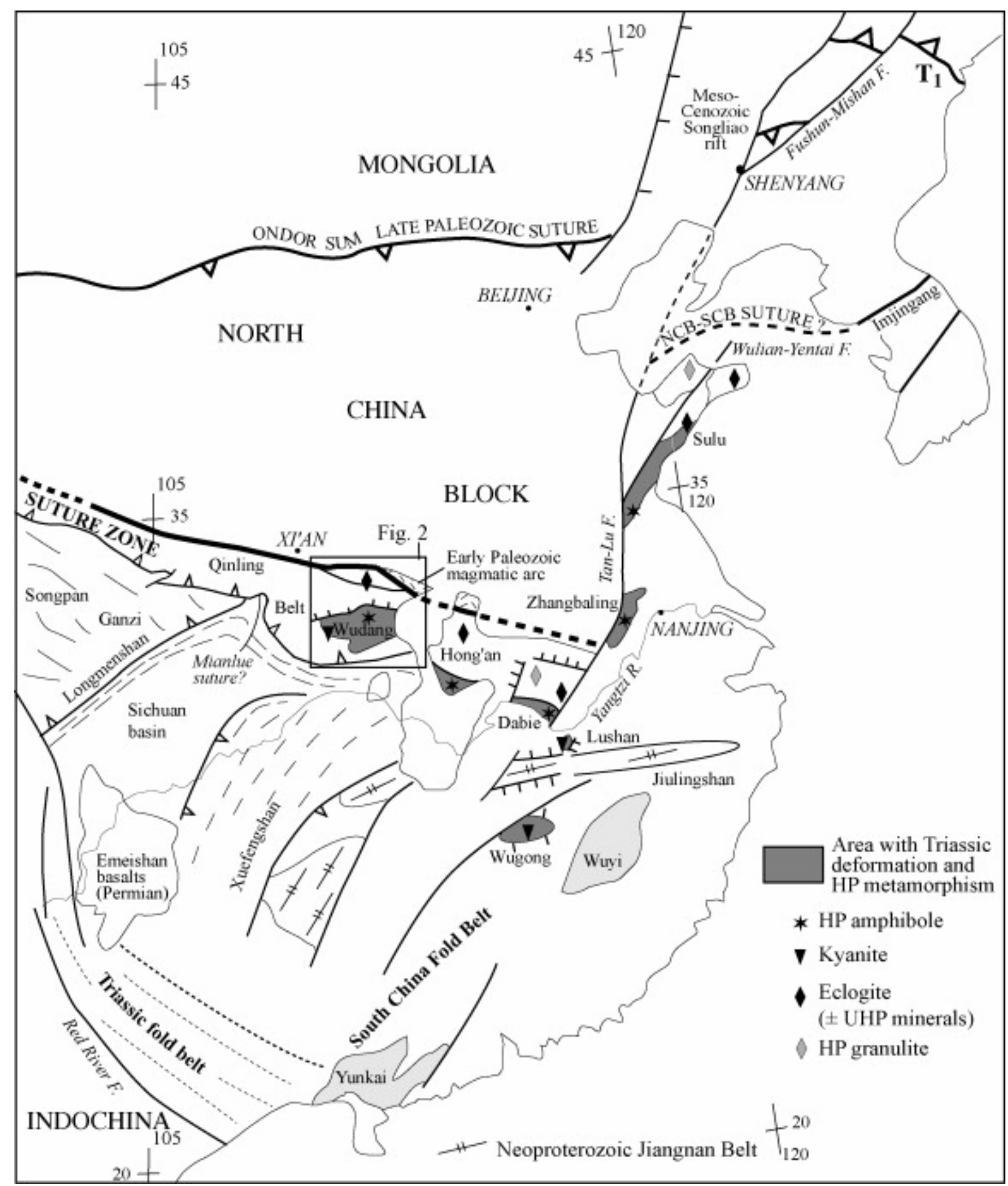

Fig. 1. Simplified tectonic map of eastern Asia, with emphasis on the Qinling-Dabie-Sulu Belt and the South China Belt, showing the main locations of the high-pressure (HP) and ultra-high-pressure (UHP) occurrences.

Fig. 1. Schéma tectonique simplifié de l'Asie orientale, mettant l'accent sur la chaîne Qinling-Dabie-Sulu et la Chine du Sud, avec la position des principales occurrences de roches de haute pression (HP) et d'ultra-haute pression (UHP). 

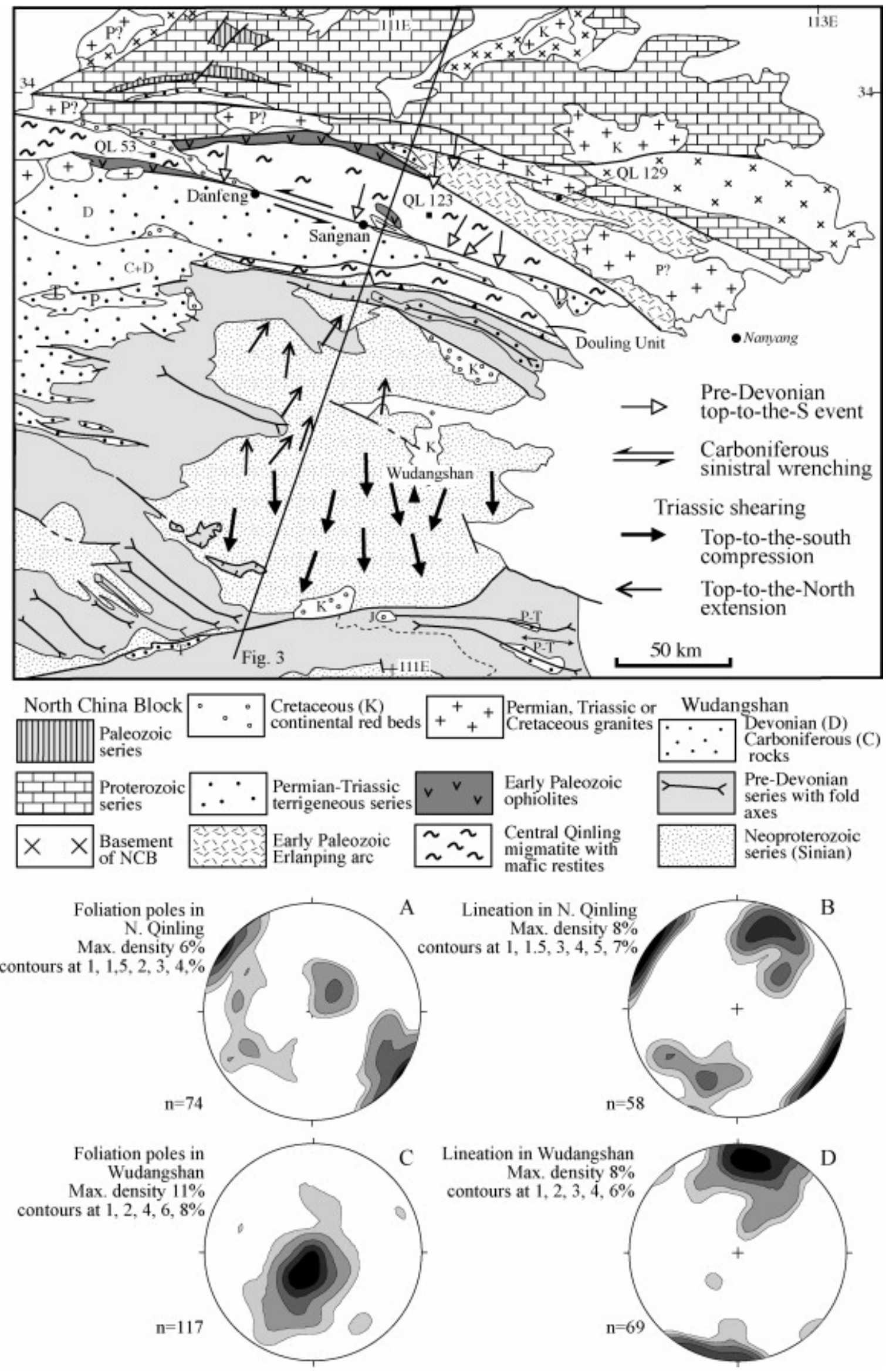
Fig. 2. Structural map of the eastern Qinling Belt. Arrows indicate the kinematics related to the different tectonic and metamorphic events (see text for details). Stereograms showing the planar and linear elements observed in the North Qinling (A \& B), and Wudangshan $(\mathbf{C} \& \mathbf{D}$; Schmidt net, lower hemisphere).

Fig. 2. Carte structurale de la partie orientale de la chaîne Qinling. Les flèches indiquent la cinématique associée aux différents événements tectono-métamorphiques (cf. texte pour les détails). Les stéréogrammes montrent les éléments planaires et linéaires observés dans le Nord Qinling (A \& B), et le Wudangshan (C \& D ; canevas de Schmidt, hémisphère inférieur).

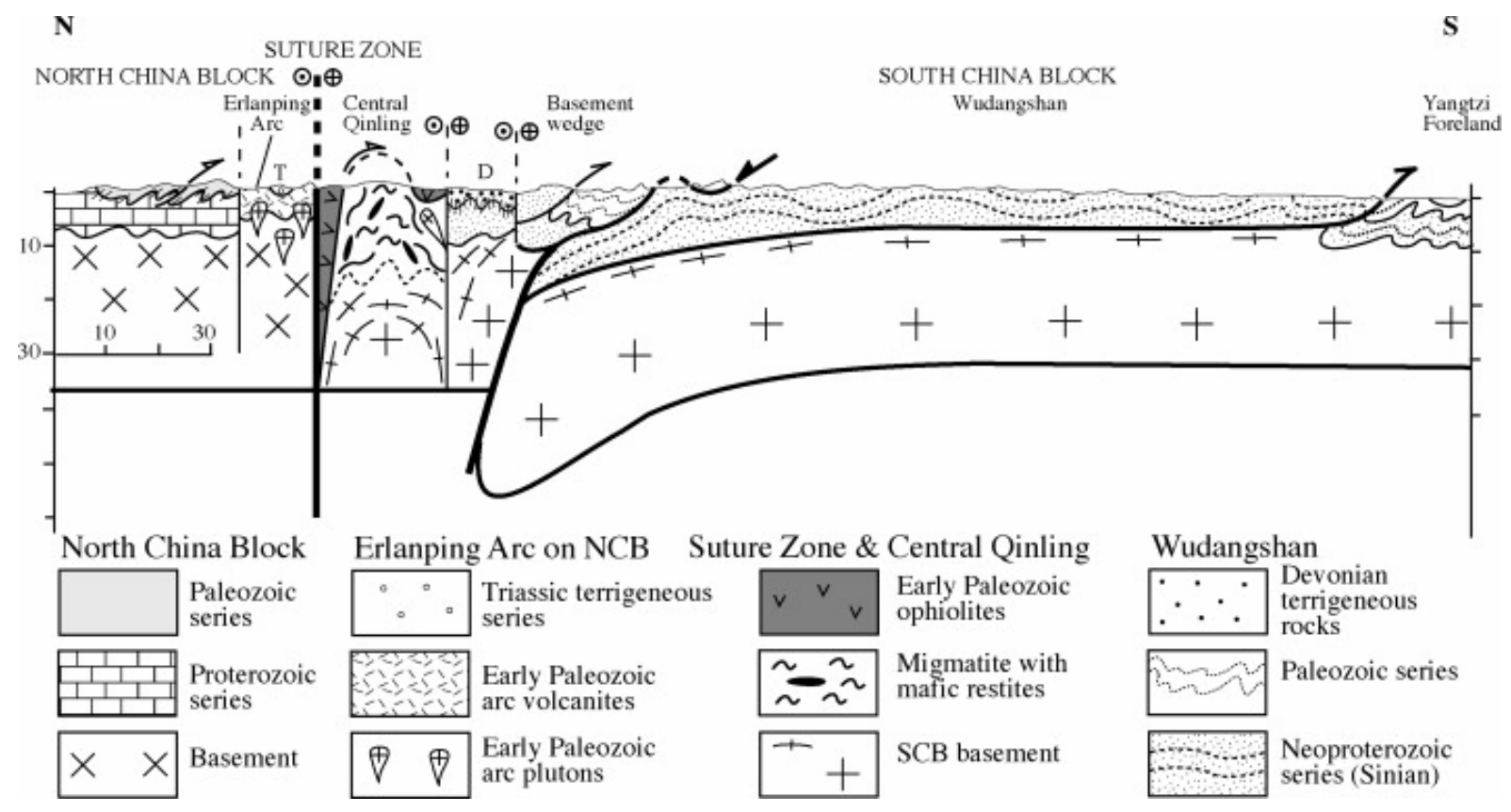

Fig. 3. Crustal-scale cross section of the eastern Qinling Belt, showing the juxtaposition of an Early Palaeozoic collisional orogen, responsible for the welding of the North China and South China blocks, and a southern Triassic intracontinental belt formed by continental subduction and exhumation of the SCB.

Fig. 3. Coupe d'échelle crustale du Qinling oriental, montrant la juxtaposition d'une chaîne de collision d'âge Paléozoïque inférieur, responsable de la soudure des blocs de Chine du Nord et de Chine du Sud, et d'une chaîne intracontinentale d'âge Triasique, formée par subduction continentale vers le nord, puis exhumation du bloc de Chine du Sud. 


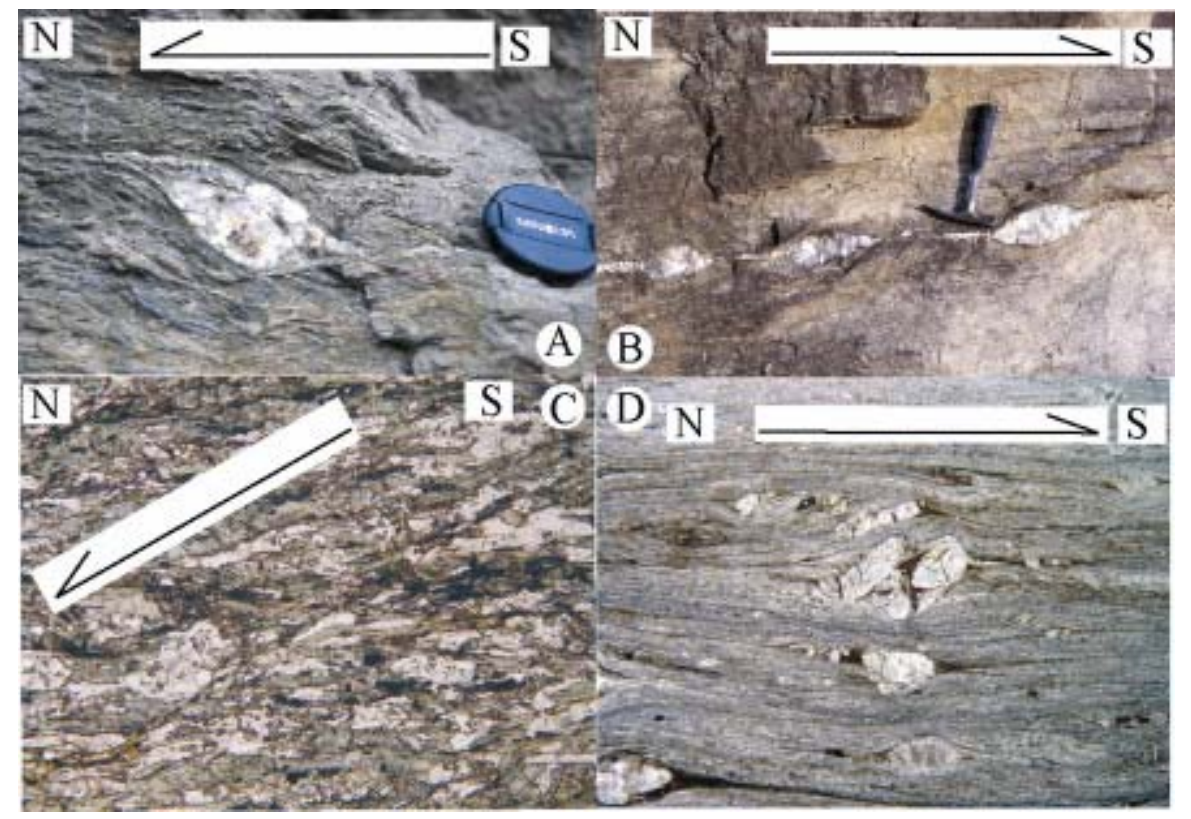

Fig. 4. Field and thin-section (cut parallel to the stretching lineation and perpendicular to the foliation) illustrations of the two types of Triassic kinematics recorded in the Neoproterozoic rocks of the Wudangshan. A \& B: Outcrop-scale sigmoidal quartz veins, $\mathbf{C}$ and $\mathbf{D}$ : thin section scale criteria. C: Top to-the-north extensional shear bands in mafic rock, D: top-tothe-south pressure shadows in acidic volcanic rock.

Fig. 4. Illustrations de terrain et de lames minces (coupées parallèlement à la linéation minérale et perpendiculairement à la foliation) des deux types de cinématiques triasiques enregistrées dans les roches d'âge Néoprotérozoïque du Wudangshan. A \& B : veines de quartz sigmoïdes à l'échelle de l'affleurement, $\mathbf{C} \& \mathbf{D}$ : critères à l'échelle de la lame mince. C : bandes de cisaillement extensives avec déplacement vers le nord de la partie supérieure dans une roche basique, $\mathbf{D}$ : cristallisation en zone abritée vers le sud dans des volcanites acides. 


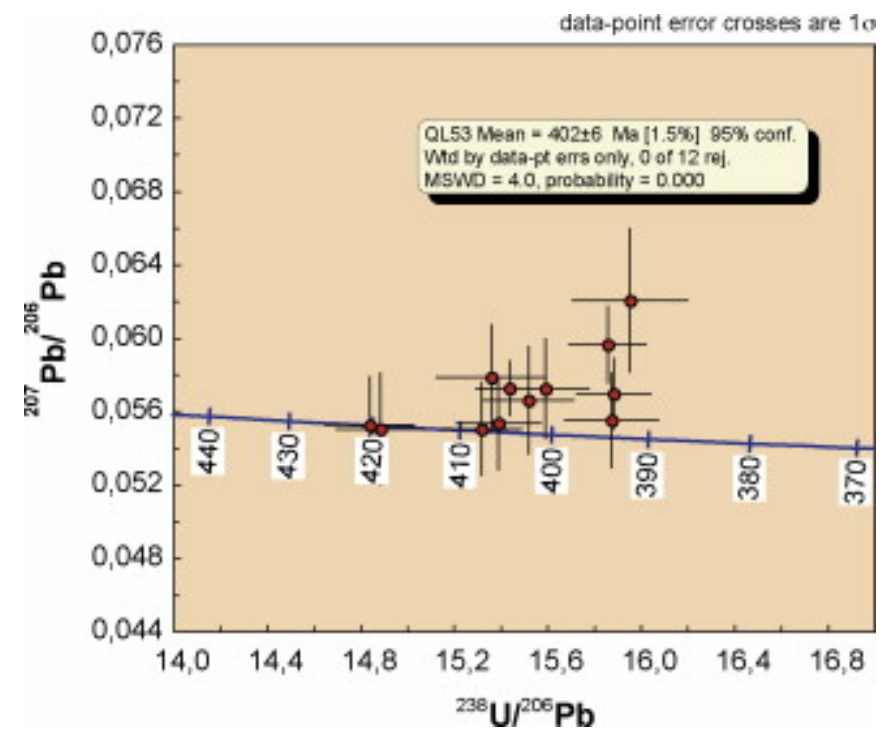

Fig. 5. Tera-Wasserburg diagram for the zircons of sample QL 53, analyzed by ICPMS.

Fig. 5. Diagramme de Tera-Wasserburg pour les zircons de 1'échantillon QL 53, analysés par ICP-MS à ablation laser.

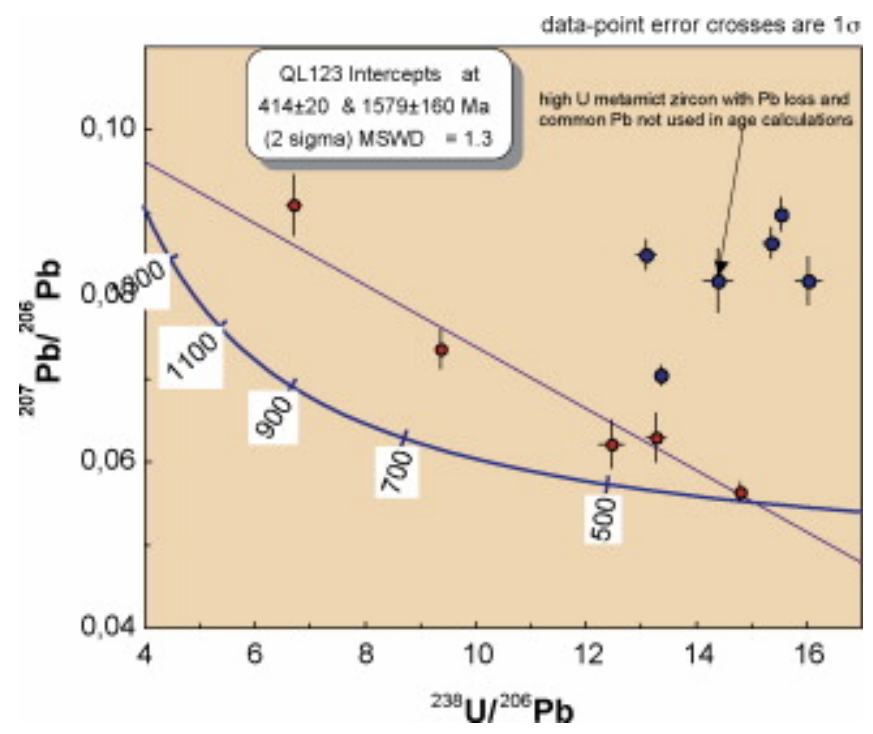

Fig. 6. Tera-Wasserburg diagram for the zircons of sample QL 123, analyzed by ICPMS.

Fig. 6. Diagramme de Tera-Wasserburg pour les zircons de l'échantillon QL 123 analysés par ICP-MS à ablation laser. 


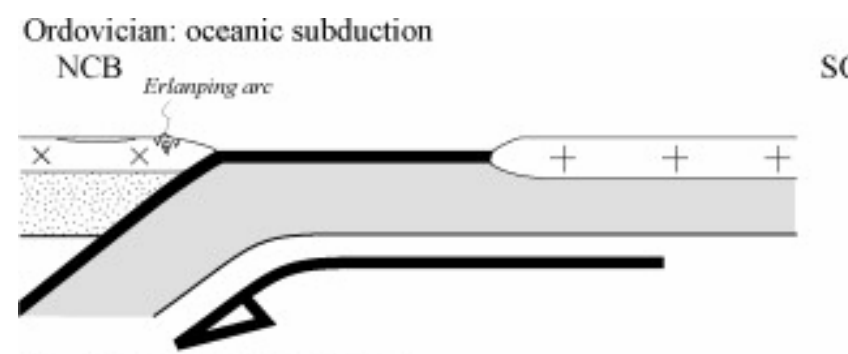

Silurian: continental collision

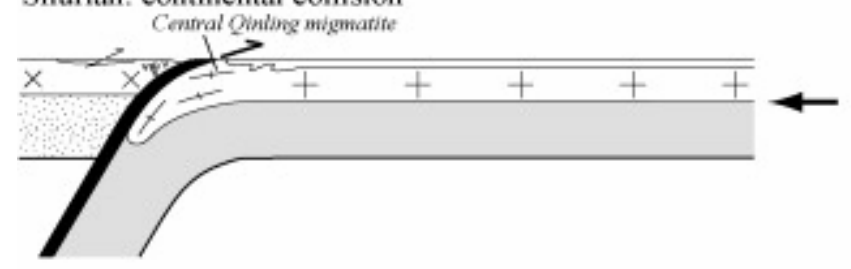

Devonian-Carboniferous-Permian: exhumation \& rifting in SCB

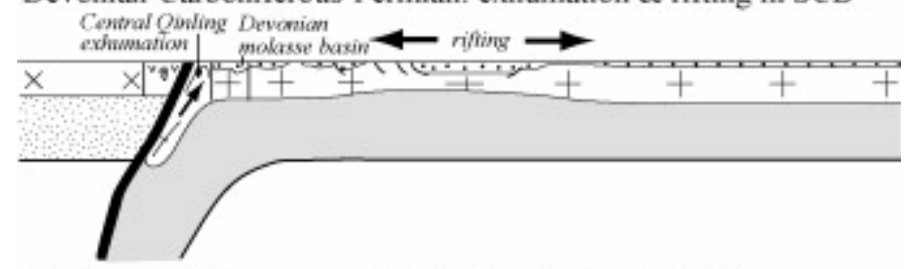

Middle to Late Triassic: continental subduction of SCB

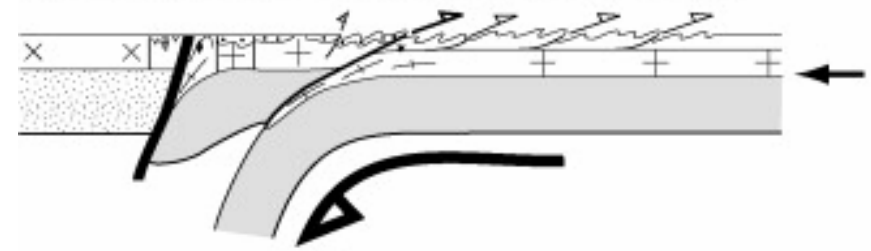

Late Triassic to Jurassic: synconvergence exhumation

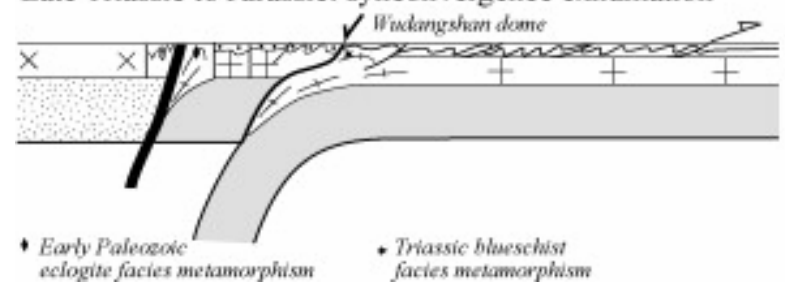

Fig. 7. Geodynamic evolution model of the NCB and SCB interactions from the Ordovician to the Late Triassic (see text for details).

Fig. 7. Modèle d'évolution géodynamique des interactions entre les blocs de Chine du Nord et de Chine du Sud entre l'Ordovicien et le Trias supérieur (voir le texte pour les détails). 